Personalidade Acadêmica Homenageada:

Augustus B. Cochran III (Agnes Scott College)

\title{
DA NECESSIDADE DE VINCULAÇÃO DO FUNDO DE DIREITOS DIFUSOS PARA EFETIVIDADE DAS REPARAÇÕES COLETIVAS
}

\section{OF THE NEED TO LINK THE DIFFUSED RIGHTS FUND FOR THE EFFECTIVENESS OF COLLECTIVE REPAIRS}

DEBORA CRISTINA DE CASTRO ROCHA Mestre em Direito Empresarial e Cidadania, Professora e Pesquisadora - Centro Universitário Curitiba - UNICURITIBA. Curitiba - PR. e-mail: debora.dcr.adv@gmail.com

\section{EDILSON SANTOS ROCHA} Pesquisador - Centro Universitário Curitiba - UNICURITIBA.- Curitiba - PR. e-mail: edilson.dcr.adv@gmail.com

\section{RESUMO}

Em se considerando que, os interesses coletivos representam um novo patamar na tutela dos direitos, pois, anteriormente prevalecia o individualismo processual, em que somente o titular do direito era legitimado para propositura de ação, o presente estudo, a partir de uma abordagem predominantemente dialética, com pesquisa bibliográfica com ênfase na literatura específica, objetiva ampliar o olhar do leitor acerca das repercussões práticas acerca da utilização dos fundos públicos para reparação coletiva, principalmente, no que diz respeito aos desastres ambientais. Criado pela Lei n- 7.347, de 24 de julho de 1985, o Fundo de Direitos Difusos - FDD, tem por finalidade a reparação dos danos causados ao meio ambiente, ao consumidor, a bens e direitos de valor artístico, estético, turístico, paisagístico, por infração à ordem econômica e a outros interesses difusos e coletivos. Constituem 
Personalidade Acadêmica Homenageada:

Augustus B. Cochran III (Agnes Scott College)

recursos do Fundo de Direitos Difusos - FDD, o produto da arrecadação de condenações judiciais, multas e indenizações relacionadas com as finalidades do Fundo, além de rendimentos auferidos com aplicações, doações e outras receitas que vierem a ele ser destinadas. Todavia, após diversas alterações normativas, fora retirada a disposição quanto à vinculação geográfica da aplicação dos recursos, em relação ao dano que Ihes deu causa. Assim, diante da desvinculação mencionada, objetiva-se, mediante este estudo, uma análise acerca das verbas depositadas no Fundo Federal de Direitos Difusos, assim como os métodos orçamentários utilizados na aplicação desses recursos, bem como sua destinação. Assim, tratar-se-á de uma discussão acerca da necessidade de vinculação das arrecadações provenientes de multas e indenizações destinadas ao Fundo de Direitos Difusos, tendo em vista o fato de que as verbas do FDD são oriundas de lesões causadas à coletividade e, por essa razão, deveriam ser aplicadas na recuperação ou promoção dos bens jurídicos lesados, reduzindo qualquer margem de discricionariedade para o gestor público. Deste modo, a primeira premissa a ser assentada é que não há qualquer hipótese de caracterização das receitas do FDD como tributos, a comporem o orçamento primário da União, por absoluta incompatibilidade com o conceito positivado no art. $3^{\circ}$ do Código Tributário Nacional, tendo em vista que as receitas são decorrentes de fontes não tributárias.

PALAVRAS-CHAVE: Fundo de Direitos Difusos; Reparação Socioambiental; Meio Ambiente; Vinculação de Receitas.

\section{REFERÊNCIAS}

Brasil. Ministério da Justiça e Segurança Pública. Disponível em: < https://www.justica.gov.br/seus-direitos/consumidor/direitosdifusos/anexos/relatorios-de-gestao/2005gestao.pdf > Acesso em: 04 jun. 2019.

Ministério Público Federal. Disponível em: < http://www.mpf.mp.br/sp/sala-de-imprensa/docs/00-peticao-inicial-acp-fdd.pdf > Acesso em: 04 jun. 2019. 
Personalidade Acadêmica Homenageada:

Augustus B. Cochran III (Agnes Scott College)

Lei no 7.347, de 24 de julho de 1985. Disciplina a ação civil pública de responsabilidade por danos causados ao meio-ambiente, ao consumidor, a bens e direitos de valor artístico, estético, histórico, turístico e paisagístico (VETADO) e dá outras providências. Disponível em: http://www.planalto.gov.br/ccivil 03/leis/l7347orig.htm > Acesso em: 04 jun. 2019.

. Lei no 5.172, de 25 de outubro de 1966. Dispõe sobre o Sistema Tributário Nacional e institui normas gerais de direito tributário aplicáveis à União, Estados e Municípios. Disponível em: < http://www.planalto.gov.br/ccivil 03/leis//5172.htm > Acesso em: 04 jun. 2019.

GURSKI. Bruno César. CALDEIRA, Violeta Sarti. SOUZA-LIMA, José Edmilson. Judicialização da Política na Tutela do Direito ao Meio Ambiente. REVISTA JURíDICA UNICURITIBA. V. $1, \quad$ N. 42, 2016, p. 419 - 438. Disponível em: < http://revista.unicuritiba.edu.br/index.php/RevJur/article/view/1515 > Acesso em: 04 jun. 2019. 